\title{
Application for Calculating Psychological Pressure in the DASS (Depression, Anxiety, and Stress Scale) Scale Using the Certainty Factor Method
}

\author{
Rudianto $^{1}$, Achmad Fitro ${ }^{2}$, Rauf Fauzan ${ }^{3}$ \\ ${ }^{1,2}$ Computer Technology NSC Polytechnic Surabaya, Indonesia \\ ${ }^{3}$ Information System Indonesian Computer University, Indonesia
}

\begin{abstract}
Psychological stresses such as depression, anxiety, and stress often experienced by students can affect academic performance, physical health, and psychosocial well-being. The purpose of this research is to build a facility in the form of a website-based application for students in particular and the general public in order to know the level of psychological pressure they are experiencing. The psychological scale used is the DASS-21 (Depression, Anxiety, and Stress Scale) and the calculation uses the Certainty Factor method. In carrying out this research, there are three main stages that are carried out, namely; The first stage, looking for literature studies related to research. Second stage, conducting interviews with experts to get a certainty value on the scale that the researcher uses. Then, build an expert system using prototype development methods and web-based applications. The third stage, implementation was carried out by getting Computer Technology student respondents. This research is a new domain for the NSC Surabaya Polytechnic which will implement an expert system by utilizing the Certainty Factor method in analyzing student stress levels through intelligent applications that will be implemented in the form of a website, with the calculation of Certainty Factors, the application can produce evidence or analysis that can be used. In changing the learning system.
\end{abstract}

KEYWORDS: Expert System, Psychological Distress, Forward Chaining, Certainty Factor

\section{INTRODUCTION}

In carrying out daily routines, we are often faced with challenges and problems that can hinder this routine. Both challenges and problems need to be resolved so that daily routines can run well. From here will arise psychological pressure that can be experienced by anyone. This is caused by the pressure that the individual gets in living his daily life. Mental health is considered an essential component of wellness by the World Health Organization. [1] An example of psychological pressure that is often experienced is stress.

Stress is one that cannot be avoided from a person's life. The source of stress for each person is different, for example the influence of surrounding environmental conditions, social relationships and the pressure experienced. Actually stress is a normal thing. No exception from the relatively young to the elderly. Everyone has their own way of dealing with the stress they experience. [2] However, there are those who are not aware of the resulting negative effects that are continuing. Depression is a type of psychological pressure that can reduce a person's interest in activities and quality of daily life. A person can be called depression if he shows a low mood; loss of interest or pleasure; guilt; low self-esteem; impaired appetite; disturbed sleep; or impaired concentration. [3] [4]

Currently, according to the 2013 Basic Health Research Data, the number of mental health professionals in Indonesia is still unable to meet the minimum quota set by the World Health Organization or WHO. In fact, WHO sets the standard for the number of psychologists and psychiatrists with a population of 1:30 thousand people, or 3.3 (rounded to 3) per 100,000 population. In other words, for a population of 250 million, about 7,500 psychology service professionals are needed. With the number of clinical psychologists and psychiatrists, Indonesia can only meet $16.3 \%$ of the total needs. In addition, to be able to access psychology services at major hospitals and psychology bureaus, visitors must pay a fairly expensive fee, on average, around Rp. 150,000250,000. If there must be other treatment such as tests and interventions, it must be at least Rp. 500,000 per visit. [5] For the student size, this is a relatively high cost. To overcome this problem, it is necessary to have facilities for students in particular and the general public in order to know the level of psychological pressure they are experiencing. Students react to tertiary education in various ways. Some think that college is difficult because of the big changes from high school days. There are also those who think that separating from home is a source of stress. [6] 


\section{International Journal of Current Science Research and Review}

ISSN: 2581-8341

Volume 03 Issue 11 November 2020

DOI: 10.47191/ijcsrr/V3-i11-08, Impact Factor: 6.595

IJCSRR @ 2020

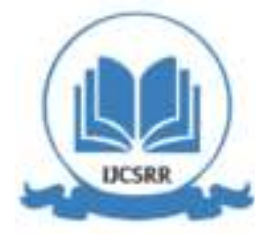

www.ijcsrr.org

The purpose of this research is to build a facility in the form of a website-based application, [7] for students in particular and the general public in order to know the level of psychological pressure they experience. This system implements expert psychology knowledge into a website-based system that provides consultation for students, just like an expert. [8] The psychological scale used is the DASS-21 (Depression, Anxiety, and Stress Scale) and the calculation uses the Certainty Factor method. [9] [10]

This research is a new domain for the NSC Polytechnic Surabaya which will implement an expert system by utilizing the Certainty Factor method in analyzing student stress levels through intelligent applications that will be implemented in the form of a website, with the calculation of Certainty Factors, the application can produce evidence or analysis that can be used. in changing the learning system..

\section{LITERATURE REVIEW}

This chapter will explain previous studies as the basis for research:

A. Application of forward chaining on e-survey decision making model for transactions [11]

In this study, using a model from Hebert A. Simon, namely the Knowledge Phase (Intelligence), the Design Phase (Design), and the Selection Phase (Choice). The knowledge phase classifies knowledge about purchasing computers according to usage. The design phase is the phase for implementing rules designed using the forward chaining method. The last phase is the selection phase to make a user decision for making transactions. The result of this research is a survey model made in the form of webbased electronic forms, which provides decisions based on the suitability of the rules of the forward chaining rules. So, the system will show the results of the transaction which can provide the final decision to the buyer according to their needs.

B. Application of an expert system on the level of depression in adolescents using certainty factors [12]

Research conducted by Joan Angelina Widians, Masna Wati and Juriah discusses the application of certainty factor methods to expert systems to determine the level of depression in adolescents. The knowledge base in this system consists of 4 levels of depression and 29 symptoms. The output of this expert system application is a description of a person's depression level and the person's depression level percentage.

c. Factors associated with psychological distress amongst outpatient chemotherapy patients: An analysis of depression, anxiety and stress using the DASS-21 [13]

These results also help in identifying high-risk subsets of the cancer population that could benefit from targeted screening for disease and providing additional support. Difficulty in cancer patients is an important complication of cancer and its treatment, contributing to worse health outcomes, increased risk of psychological comorbidities and increased utilization of health care services.

D. The effect of substance abuse on depression, anxiety, and stress (DASS-21) in epileptic patients [14]

This study concludes that some drug addicts are directed at substance abuse for pain relief from chronic disease rather than behavioral disorders, which need special attention in preventing and treating addicts. More people are likely to become drug addicts because of psychosocial problems associated with chronic illness, but do not go to addiction treatment clinics or specialized help centers; Therefore, symptoms of depression, anxiety and stress play an important role in the propensity of people with epilepsy to abuse drugs. The role of counseling and treatment of psychic disorders in a timely manner will be effective in reducing patient problems

\section{E. Testing comparison models of DASS-12 and its reliability among adolescents in Malaysia [15]}

This study shows that 12 usable and used DASS items are considered to have stable factorial validity, adequate reliability and to serve as a measure of validity used among adolescents in clinical or research assessments and outpatient treatment outcome measures.

\section{METHOD AND DATA}

Research design is needed to make the research process orderly and directed. In this study, the compilers used a descriptive research type. Compilers make observations and analyze everyday phenomena that occur in the object of research. From this analysis material, the authors design and manufacture the system as an action of the problems that occur. 


\section{International Journal of Current Science Research and Review}

ISSN: 2581-8341

Volume 03 Issue 11 November 2020

DOI: 10.47191/ijesrr/V3-i11-08, Impact Factor: 6.595

IJCSRR@ 2020

www.ijcsrr.org

The following is the flow of research carried out in this study, described in Fig.1:

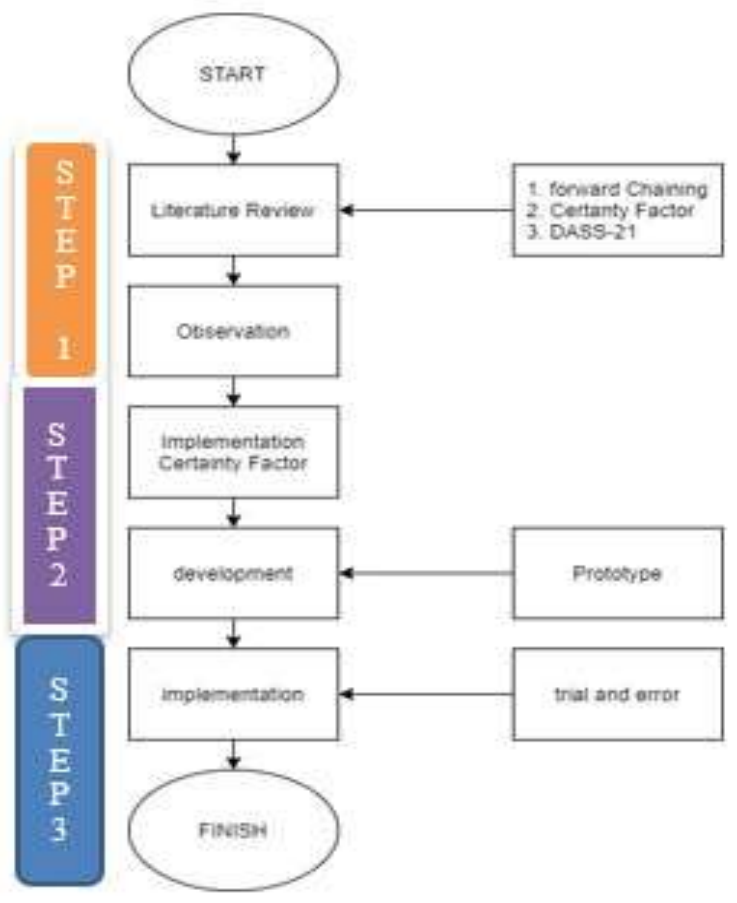

Fig 1. Research Flow

In this research, the first step to take is to look for literature studies related to research. Learn about forward chaining as an expert system reasoning method to be built, the certainty factor method as a method for solving the uncertainty problem in this study, and the psychological scale for calculating the level of psychological pressure, namely DASS-21. After studying, the researcher conducts interviews with experts to obtain a confidence value (cf) on the scale the researcher uses.

Second stage, from the results of the interview, the expert interpreted the terms consisting of "don't know" to 0.2, "possible" to 0.4, "high probability" to 0.6 , "almost certain" to 0.8 , and "certain" to 1 Then, build an expert system using the prototype development method. The following are the stages of using the prototype development method:

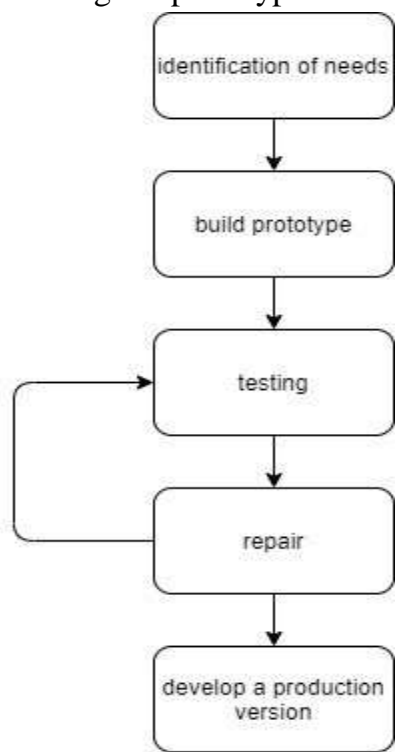

Fig 2. Prototype Development Methode [16] 


\section{International Journal of Current Science Research and Review}

ISSN: 2581-8341

Volume 03 Issue 11 November 2020

DOI: 10.47191/ijcsrr/V3-i11-08, Impact Factor: 6.595

IJCSRR@ 2020

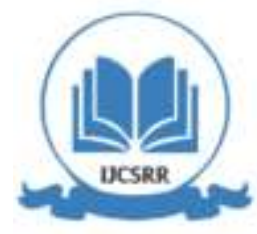

Www.ijcsrr.org

The following are the stages of the Prototype method:

A. Collection of Needs

In this stage the user and the developer jointly define the format of the entire software, identify all requirements, and a general image of the system to be created.

\section{B. Build Prototype}

Build prototyping by making temporary designs that focus on serving customers (for example by creating input and output formats).

\section{Evaluation Protoptyping}

This evaluation is carried out by the customer whether the prototyping that has been built is in accordance with the customer's wishes. If it is appropriate then step 4 will be taken. If not, the prototyping is revised by repeating steps 1,2 , and 3 .

\section{Develop Product Versions}

In this stage the prototyping that has been agreed upon is translated into the appropriate programming language. After the system has become a ready-to-use software, it must be tested before use. This test is done with White Box, Black Box, Base Path, architectural testing and others.

The third stage, an expert system built on a web based. Implementation is done by getting computer technology in NSC Polytechnic Surabaya. From the results of calculations carried out by the system, the researcher makes comparisons with the results of calculations made by expert psychologist.

\section{RESULTS AND DISCUSSION}

In designing the knowledge base, the relationship between symptoms in the form of statements and categories of psychological pressure based on DASS-21 will be discussed. As the name implies, DASS-21 consists of 21 statements that cover 3 categories of stress namely depression, anxiety and stress. DASS-21 is a simplification of DASS-42. Each pressure category has 5 levels, namely normal, low, moderate, heavy and very heavy. For the calculation, the total number of each of the 7 statements is multiplied by two. Apart from that, the rules and regulations that will be used along with the discussion of cf values from experts. Based on the knowledge base that the author uses, there are 3 categories of psychological stresses shown by T1, T2, T3 and 21 statements shown by $\mathrm{P} 01, \mathrm{P} 02, \ldots, \mathrm{P} 21$. From the 21 statements and 3 pressure categories, a relationship is compiled which is used as a basis for making conclusions. In addition, each pressure category has 5 types of levels. The following is a pressure category table, a statement table table, and a level table.

\section{A. Calculation of Certainty Value}

One theory that can be used to solve the uncertainty problem is the Certainty Factor theory. Certainty Factor or CF is a value to measure expert confidence. The following is the cf value obtained by the authors from experts and literature.

Table 1. Table of rules CF [5]

\begin{tabular}{ccc}
\hline Statement & Pressure & CF \\
\hline P01 & T3 & 0.4 \\
P02 & T2 & 0.2 \\
P03 & T1 & 0.4 \\
P04 & T2 & 0.4 \\
P05 & T1 & 0.4 \\
P06 & T3 & 0.4 \\
P07 & T2 & 0.4 \\
P08 & T3 & 0.6 \\
P09 & T2 & 0.4 \\
P10 & T1 & 0.6 \\
P11 & T3 & 0.8 \\
P12 & T3 & 0.6
\end{tabular}




\section{International Journal of Current Science Research and Review}

ISSN: 2581-8341

Volume 03 Issue 11 November 2020

DOI: 10.47191/ijesrr/V3-i11-08, Impact Factor: 6.595

IJCSRR@ 2020

Www.ijcsrr.org

$\begin{array}{lll}\text { P13 } & \text { T1 } & 0.6 \\ \text { P14 } & \text { T3 } & 0.4 \\ \text { P15 } & \text { T2 } & 0.6 \\ \text { P16 } & \text { T1 } & 0.6 \\ \text { P17 } & \text { T1 } & 0.6 \\ \text { P18 } & \text { T3 } & 0.6 \\ \text { P19 } & \text { T2 } & 0.4 \\ \text { P20 } & \text { T2 } & 0.6 \\ \text { P21 } & \text { T1 } & 0.6\end{array}$

After getting the CF value from experts and literature, a certainty factor will be calculated to produce a value of confidence or certainty for the diagnosis that has been carried out. Based on the results of the interview, the CF expert was obtained. Therefore, the implementation of this psychological pressure expert system will use the formula in equation (1):

$$
C F \text { combine }=C F_{1}+C F_{2} *\left[1-C F_{1}\right]
$$

Because the given $\mathrm{CF}$ value is positive. The formula can then be applied to several different rules or rules.

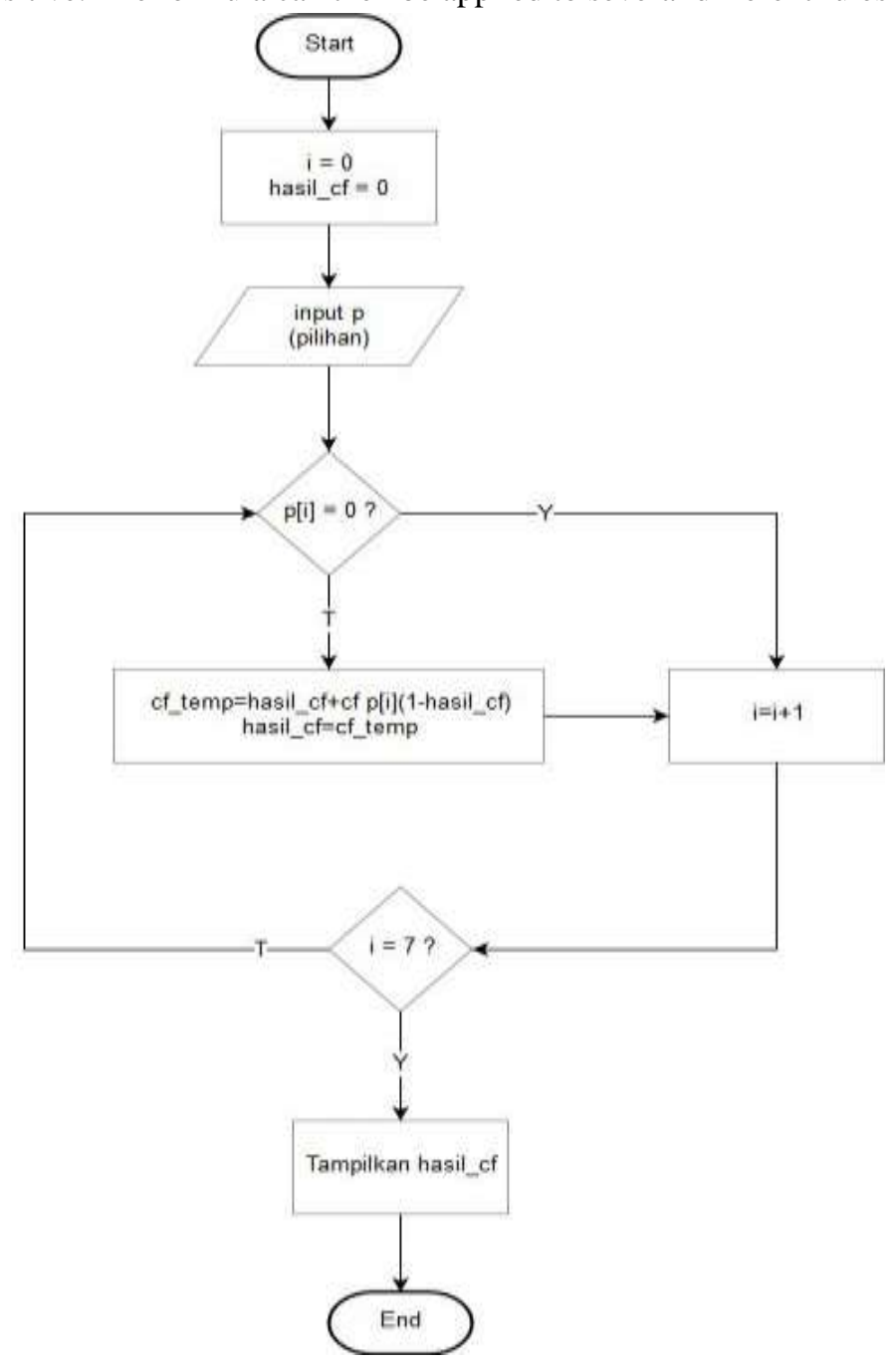

Fig 3. Flowchart calculation $\mathrm{CF}$

The following is an example of calculating CF on one of the psychological pressures, namely depression. Students fill in the choices on P03, P05, P10, P13, P16, P17, P21 


\section{International Journal of Current Science Research and Review}

ISSN: 2581-8341

Volume 03 Issue 11 November 2020

DOI: 10.47191/ijesrr/V3-i11-08, Impact Factor: 6.595

IJCSRR@ 2020

www.ijcsrr.org

1) $\mathrm{CF} \mathrm{P03}, \mathrm{P05}$

$=0.4+0.4(1-0.4)$

$=0.64$

2) $\mathrm{CF} P 03, \mathrm{P05}, \mathrm{P} 10$

$=0.64+0.6(1-0.64)$

$=0.856$

3) $\mathrm{CF} P 03, P 05, P 10, P 13$

$=0.856+0.6(1-0.856)$

$=0.9424$

4) $C F P 03, P 05, P 10, P 13, P 16$

$=0.9424+0.6(1-0.9424)$

$=0.97696$

5) $C F P 03, P 05, P 10, P 13, P 16, P 17=C F P 03, P 05, P 10, P 13, P 16+C F P 17(1-C F P 03, P 05, P 10, P 13, P 16)$

$=0.97696+0.6(1-0.97696)$

$=0.990784$

6) $C F P 03, P 50, P 10, P 13, P 16, P 17, P 21=C F P 03, P 05, P 10, P 13, P 16, P 17+C F P 21$ (1-CF P03,P05,P10,P13,P16,P17)

$=0.990784+0.6(1-0.990784)$

$=0.9963136$

So that the value of 0.9963136 or $99.631 \%$ is obtained as the value of confidence that the student is depressed.

\section{B. System Design}

System design is a description and scheme of the system to be built. At this stage of the system design will be discussed about system design using the Usecase diagram.

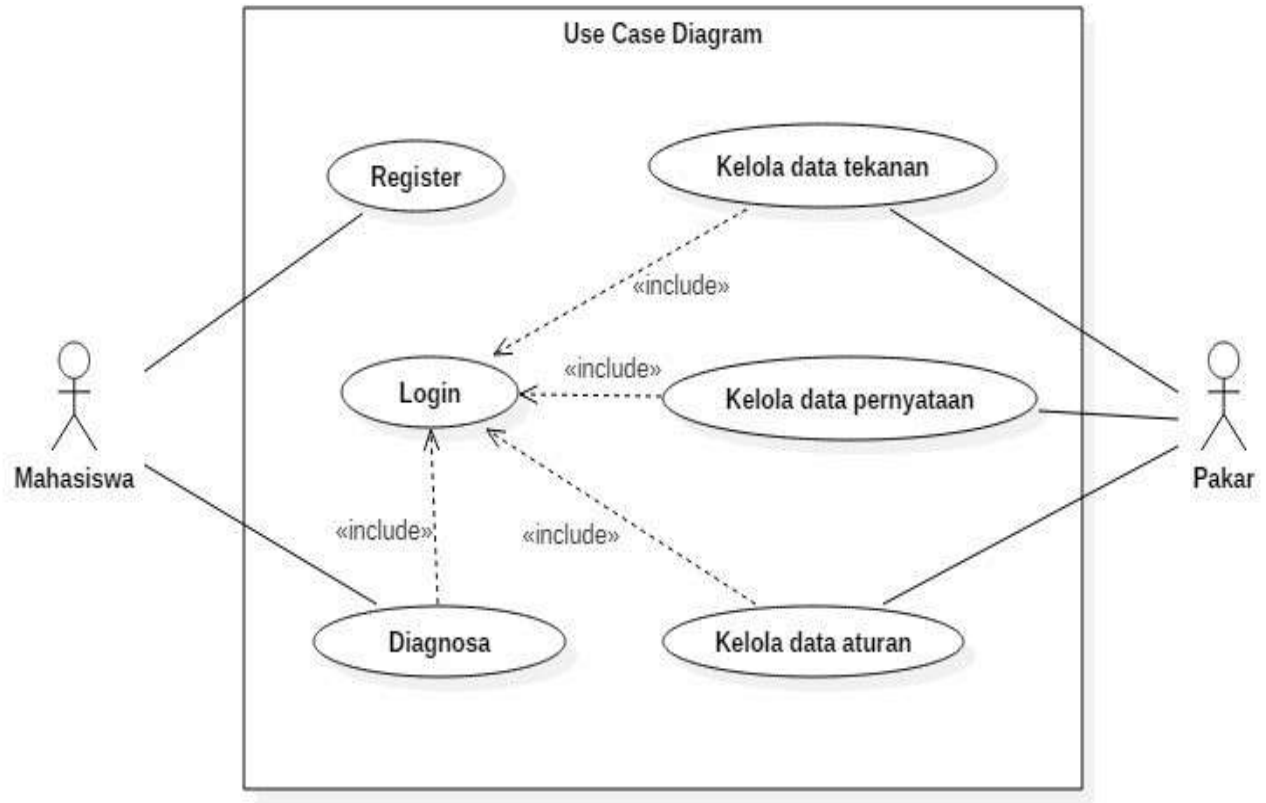

Fig 4. Use Case Diagram System

\section{Data Design}

The data design is described using class diagrams. Class diagrams describe the system structure in terms of defining the classes that will be made to build the system. Each class has attributes and methods or operations. The following is the class diagram on the system: 


\section{International Journal of Current Science Research and Review}

ISSN: 2581-8341

Volume 03 Issue 11 November 2020

DOI: 10.47191/ijesrr/V3-i11-08, Impact Factor: 6.595

IJCSRR@ 2020

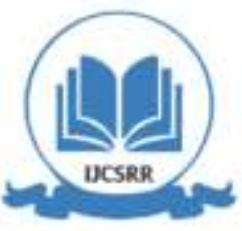

www.ijcsrr.org

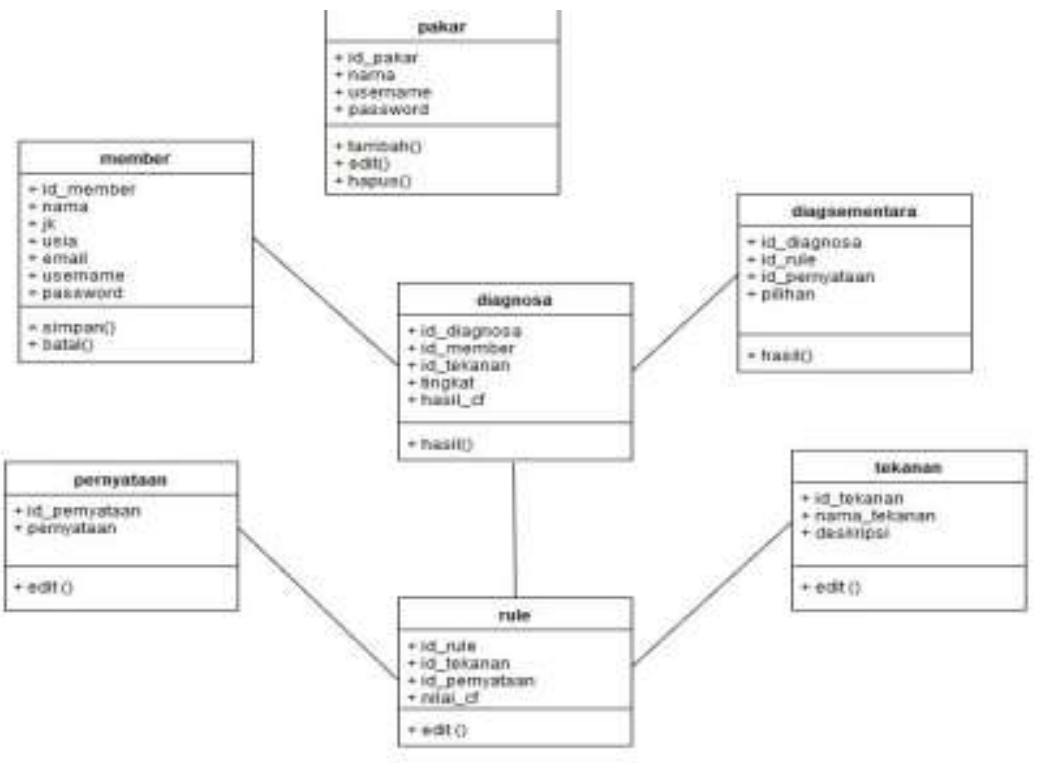

Fig 5. Class Diagram System

D. Implementation

Implementation is described in the form of application implementation. Users who use there are 2 roles, namely the role of the expert and the role of the student. Here are some views of the psychological pressure calculation application:

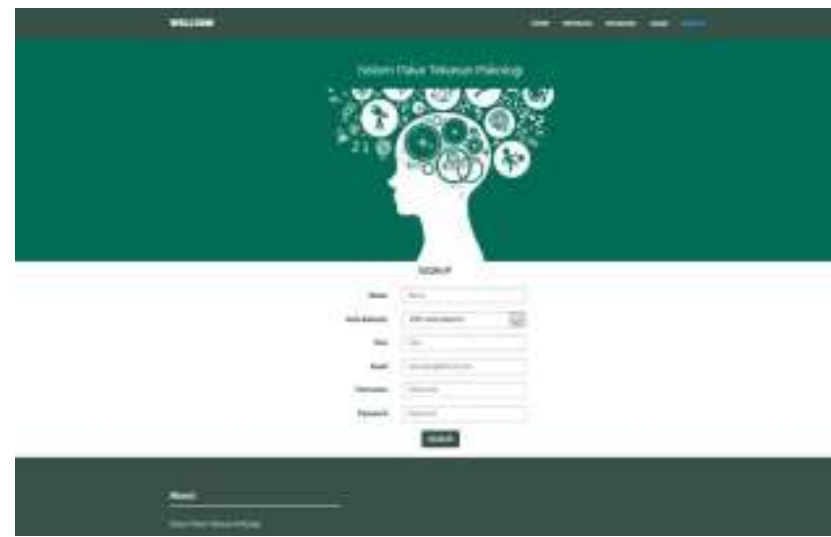

Fig 6. Student Registration Page

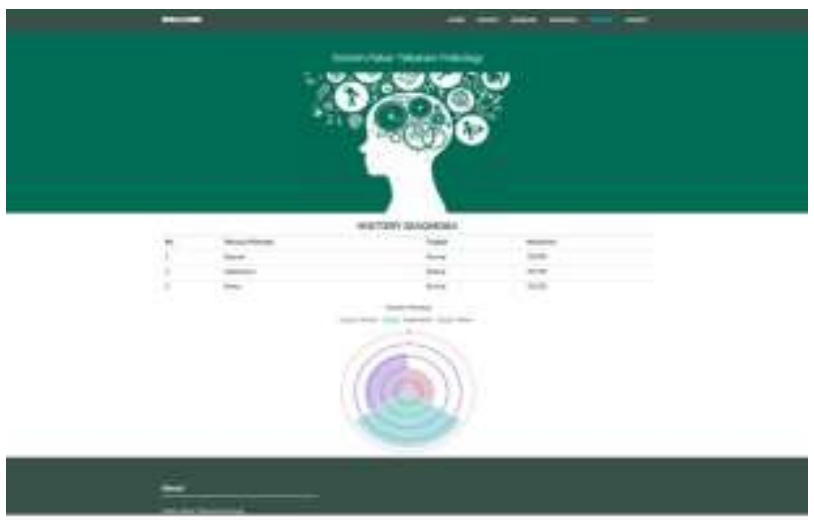

Fig 8. Student Diagnosis Detail Page

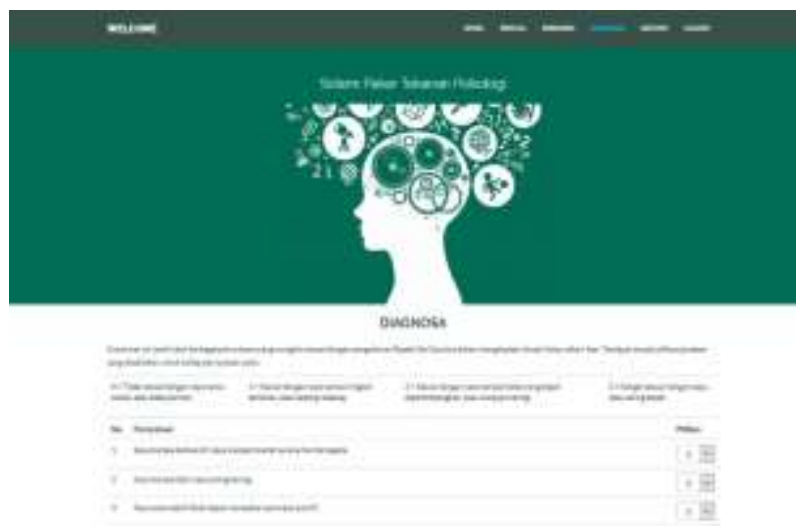

Fig 7. Student Diagnosis Page
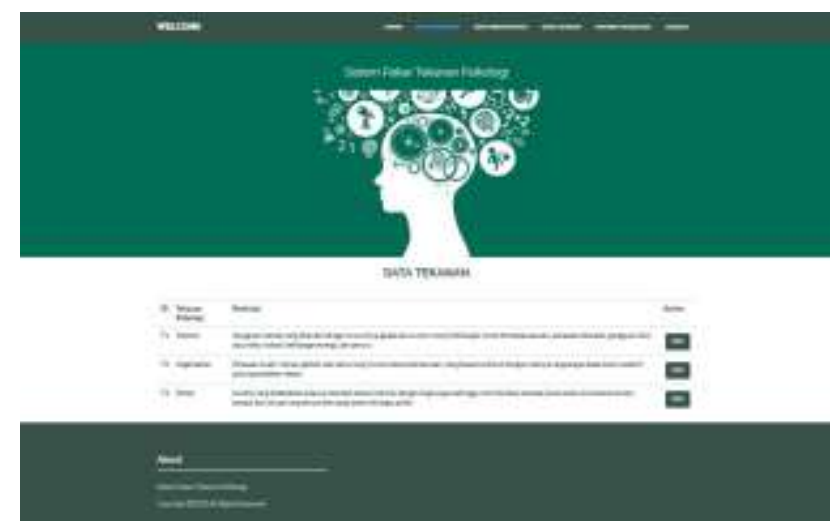

Fig 9. Pressure Data Page 


\section{International Journal of Current Science Research and Review}

ISSN: 2581-8341

Volume 03 Issue 11 November 2020

DOI: 10.47191/ijcsrr/V3-i11-08, Impact Factor: 6.595

IJCSRR@ 2020

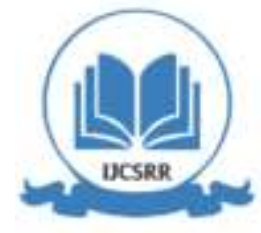

Www.ijcsrr.org

Unlike the student display, the expert page is specifically for experts inputting question parameters that will be given to students. Here's how it looks:
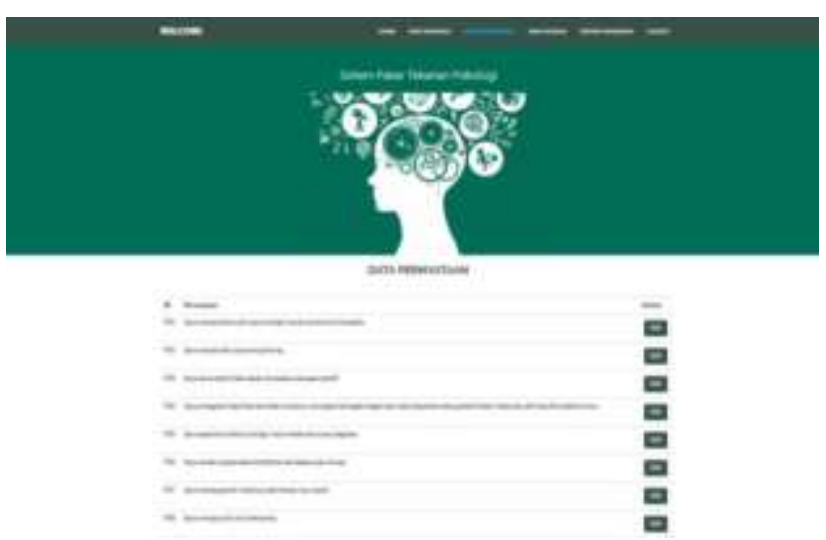

Fig 10. Statement Data Page Fig
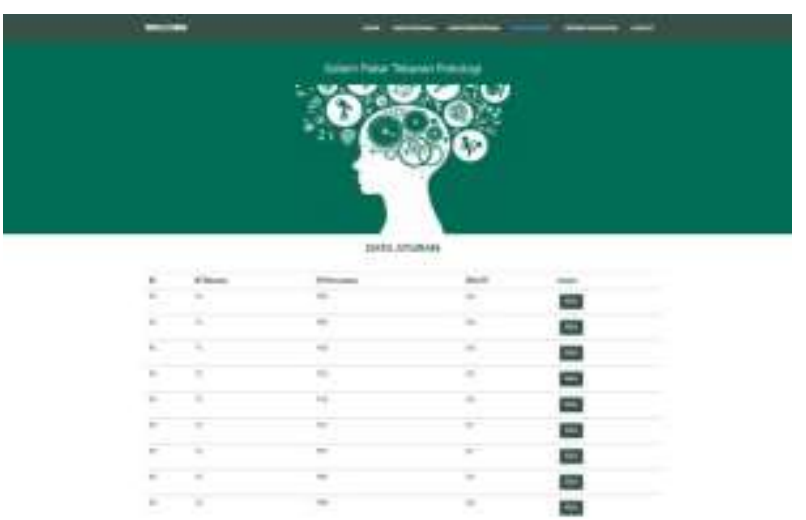

Fig 11. Rules Data Page

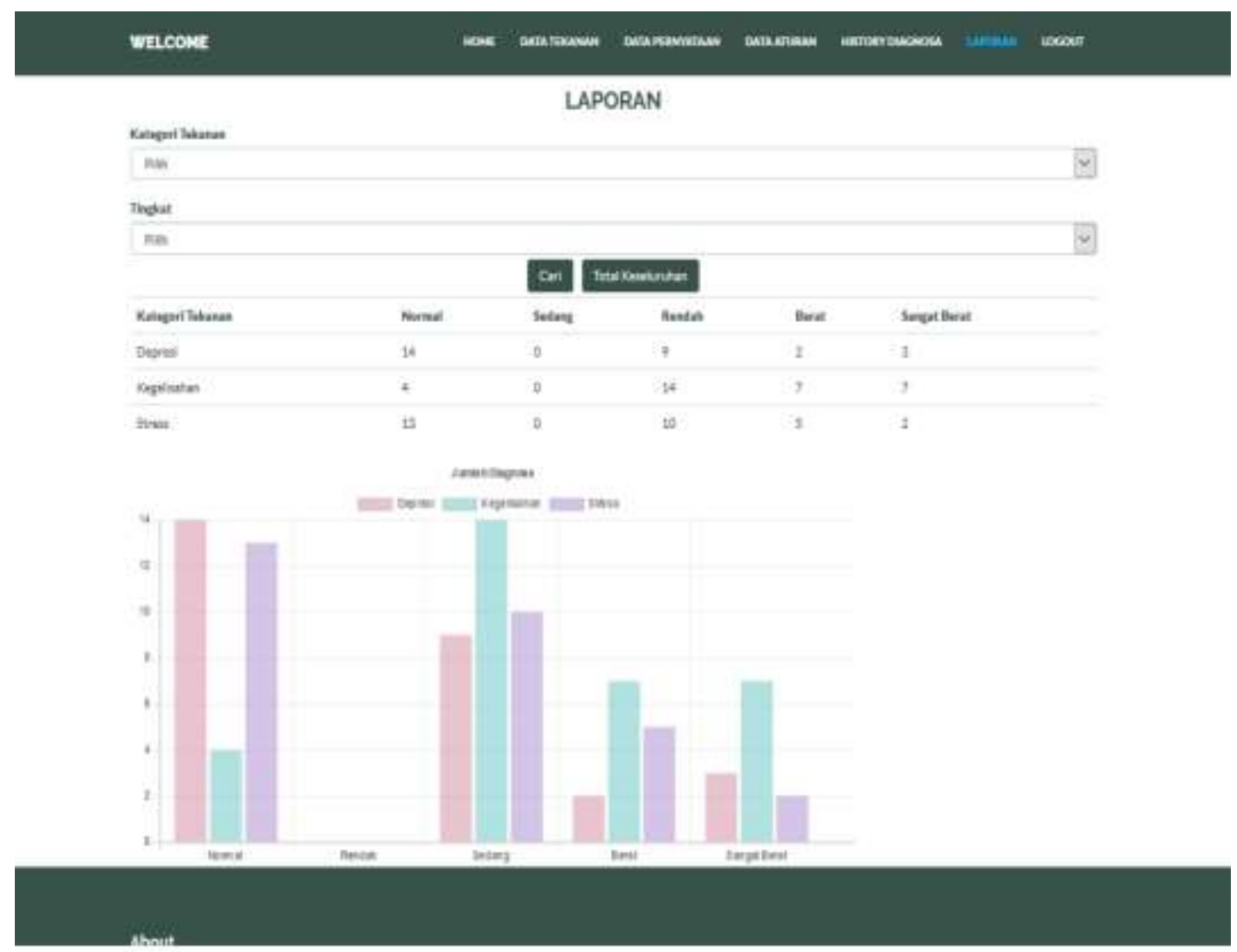

Fig 12. Report

\section{CONCLUSION}

From the results of the above discussion, several points can be concluded, among them: With this system, it can help students to find out about psychological pressure, helps students to be more aware of the importance of knowing the psychological pressure they experience so as not to cause lasting negative effects, this system can work like an assistant who can help psychologists to measure the level of a person's psychological pressure and can be an alternative for students who want to know the level of psychological pressure. 


\section{International Journal of Current Science Research and Review}

ISSN: 2581-8341

Volume 03 Issue 11 November 2020

DOI: 10.47191/ijesrr/V3-i11-08, Impact Factor: 6.595

IJCSRR@ 2020

WWw.ijcsrr.org

\section{REFERENCES}

1. M. Marcus, M. T. (2012). Depression, A Global Public Health Concern. Geneva World Heal.

2. Rime, B. (2016). Self disclosure. Dalam H. S. Friedman (Ed.), Encyclopedia of Mental Health (ed. 2, vol. 4) (pp. 66- 74). Waltham, MA: Academic Press.

3. Zhang, R. (2017). The stress buffering effect of self disclosure on Facebook: An examination of stressfull life events, social support, and mental health among college students. Journal Computer in Humans Behaviour, 75, 527-537

4. Weinberg, R. S., \& Gould, D. (2003). Foundations of Sport and Exercise Psychology, 3rd ed. Champaign, IL: Human Kinetics.

5. Fitro, A \& Tamjis, A.Q. (2018). Design of Web-Based Legislative Candidate Application. Journal of Information Systems \& Applied Computer Science. 2614-0918

6. Ika. (2015). UGM News. Retrieved from UGM News:

https://ugm.ac.id/id/berita/9715- minim.psikolog.ribuan.penderita.gangguan.jiwa.belum.tertangani

7. Joan, \& Masna, J. (2017). Aplikasi Sistem Pakar Tingkat Depresi Certainty Factor. Seminar Nasional Teknologi Informasi dan Multimedia (pp. 1-6). Yogyakarta: STIMIK APTIKOM.

8. Andriani, A. (2017). Pemrograman Sistem Pakar. Yogyakarta: Mediakom

9. Kumaraswamy, N. (2013). Academic Stress, Anxiety and Depression among College Students - A Brief Review. Int. Rev. Soc. Sci. Humanit, 135-143.

10. Sutojo, T., Mulyanto, E., \& Suhartono, V. (2011). Kecerdasan Buatan. Yogyakarta: Andi Offset

11. Purnomo, D. (2017). Model Prototyping Pada Pengembangan Sistem Informasi. Jurnal Informatika Merdeka Pasuruan, 54-61.

12. Nursikuwagus A \& Renggana, A. (2014). APPLICATION OF FORWARD CHAINING ON E-SURVEY DECISION MAKING MODEL FOR TRANSACTIONS. Conference: Quality Information and Knowledge. Volume 11

13. Widians, J.A \& Wati, M. (2017). Aplikasi Sistem Pakar Tingkat Depresi Certainty Factor.

14. McMullen, M., Lau, P.K.H., Taylor, S., McTigue, J., Cook, A., \& Hasani, A. (2018). Factors associated with psychological distress amongst outpatient chemotherapy patients: An analysis of depression, anxiety and stress using the DASS-21. Applied Nursing Research. 40 (2018) 45-50

15. Farnia, V., Afshari, D., Abdoli, N., Radmehr, F., Moradinazar, M., Alikhani, M., Behrouz, B., Khodamoradi, M., \& Farhadian, N. (2020). The effect of substance abuse on depression, anxiety, and stress (DASS-21) in epileptic patients. Clinical Epidemiology and Global Health. https://doi.org/10.1016/j.cegh.2020.08.001

16. Fitro, A., \& Prasetyo, H. (2020). System Pendukung Keputusan Dalam Menentukan Bidang Usaha Menggunakan Metode Analytic Hierarchy Process Pada Penerima Bantuan Laz Sidogiri. Jurnal Technopreneur, 8(2), 82 - 89. https://doi.org/10.30869/jtech.v8i2.619

Cite this Article: Rudianto, Achmad Fitro, Rauf Fauzan (2020). Application for Calculating Psychological Pressure in the DASS (Depression, Anxiety, and Stress Scale) Scale Using the Certainty Factor Method. International Journal of Current Science Research and Review, 3(11), 185-193 